\title{
Counting Efficiency
}

National Cancer Institute

\section{Source}

National Cancer Institute. Counting Efficiency. NCI Thesaurus. Code C94879.

The observed count rate divided by that expected if all events were counted. 